\title{
亜寒帯河川流域の流出に与える山岳水河の影響について
}

\author{
和田 知之 ${ }^{* 1} \cdot$ 知北 和久 ${ }^{* 2} \cdot$ 工藤 熏 ${ }^{* 3} \cdot$ 城戶 大作 ${ }^{* 1} \cdot$ 成田 悠一 ${ }^{* 1}$

\section{Glacial effects on discharge, sediment load and water chemistry from a subarctic river basin.}

\author{
Tomoyuki WADA ${ }^{* 1}$, Kazuhisa A. CHIKITA *2, Isao KUDO *3, \\ Daisaku KIDO *1, Yu-ichi NARITA *1
}

\begin{abstract}
The subarctic Tanana River basin, Alaska, is occupied by ca. $5.6 \%$ glacierized region and the other discontinuous permafrost region. Time series of discharge, suspended sediment concentration (SSC) and water chemistry in the Tanana River were obtained in the glacier-melt seasons of 2000 to 2005. In order to estimate each contribution of glacier-melt to discharge, SSC and water chemistry, all the time series were reproduced by the tank model. As a result, the reasonable simulations (correlation coefficient $R=0.68-0.97$ ) for the discharge time series revealed that glacial-melt discharge occupies $33-58 \%$ of the Tanana river discharge. The SSC and $\mathrm{SiO}_{2}$ time series were also reasonably simulated ( $\mathrm{R}=0.70-0.87$ ). These calculations led to the conclusion that the major sediment and $\mathrm{SiO}_{2}$ sources are located in the glacierized and permafrost regions, respectively.
\end{abstract}

Key words: glacier, permafrost, sediment load, water balance, tank model, rating curve キーワード：水河, 永久凍土, 土砂流出, 水収支, タンクモデル, L-Q 式

\section{। はじめに}

亜極域には，流域内に永河域と不連続な永久凍 土域がある河川が存在し，水河及び活動層の凍土 の融解と降雨が夏季の主要な涵養源となっている (知北ほか , 2006; Chikita et al., 2007)。水河域か らの流出は,気温に大きく影響される (Kido et al., 2007)。一方, 凍土域からの流出は, 雨水か唀水性 の高い上部有機層を速やかに浸透し, 透水性の低
い下部無機層に遮られて生じる地中流が主な成分 である (Woo and M arsh, 2005)。

土砂流出については, 水河域と凍土域では逆の 性質を持っており，氷食作用により大きな土砂供 給源となっている水河域に対し, 強固な凍土は浸 食を受けにくい(知北ほか, 2006)。また, 植物 プランクトンの生産に重要な $\mathrm{SiO}_{2}$ の流出水中の 濃度は, 水河域からの流出に比べて凍土域からの 流出の方が高い (Anderson et al., 2000; Guo and

* 1 北海道大学大学院理学研究科地球惑星科学専攻 Division of Earth and Planetary Sciences, Graduate School of Science, Hokkaido University

*2 北海道大学大学院理学研究院自然史科学部門 Department of $\mathrm{N}$ atural History Sciences, Faculty of Science, Hokkaido University

*3 北海道大学大学院水産科学研究院海洋環境科学分野 Division of M arine Environment and Resources, Faculty of Fisheries, Hokkaido University 
M acdonald, 2006)。

海洋への淡水流入は冬季の海永生成, 土砂や栄 養塩流入は海洋での基礎生産量に大きな影響を与 える。しかし，流域内に水河と凍土が共存する大 河川の流出機構については，これまで研究例が乏 しく，不明な点が多い (M eade et al., 2000)。他 方, 近年の温暖化傾向や降水量変化は, 流域や海 洋に影響を及ぼすことが考えられる。光こで，本 研究ではユーコン川支流の中でも水河被覆域の比 較的大きなタナナ川流域に焦点をあて，水河域及 び東土域の流出への寄与を定量的に評価すること によって , タナナ川の流出機構を明らかにするこ とを目的とする。現地観測によりタナナ川の水 · 土砂・化学物質の流出特性を調ベ, タンクモデル によって観測で得られた時系列データの解析を行 い, 水・土砂・化学物質の流出に対する水河域及 び凍土域の寄与を明らかにした。

\section{II 研究地域と観測データ}

\section{II- 1 研究地域}

研究地域は, アラスカ・ユーコン川の支流であ るタナナ川の NEN 地点 (Fig. 1) より上流の流域 である。NEN 地点はユーコン川との合流点から $208 \mathrm{~km}$ 上流に位置し, 流域面積は $6.63 \times 10^{4} \mathrm{~km}^{2}$ で，これは北海道の面積 $8.35 \times 10^{4} \mathrm{~km}^{2}$ に匹敵す る。流域南側源頭部のアラスカ山脈付近とランゲ ル山群付近には, 水河域が存在している (Fig. 1)。 水河域の決定にはランドサットデータを用い，光 の面積は流域全体の約 5.6\%であった。水河域の 下流には不連続な永久凍土が広がり，地上には針 葉樹林, 広葉樹林, 潅木, 草などが生えている。 タナナ川の河道周辺には湿地帯があり， シート状 永久凍土や永久凍土塊が存在する (Ferrians, 1965; Brown et al., 1997; Brabets et al., 2000)。

PC 地点 (Fig. 1) はガルカナ水河末端の下流 $1.1 \mathrm{~km}$ にあり, 流域面積 $31.1 \mathrm{~km}^{2}$ のうち $19.8 \mathrm{~km}^{2}$ が水河である。ガルカナ水河では長期間の水文 · 気象観測がなされていることから，タナナ川流域 内の水河域では流出に関する研究が比較的多く

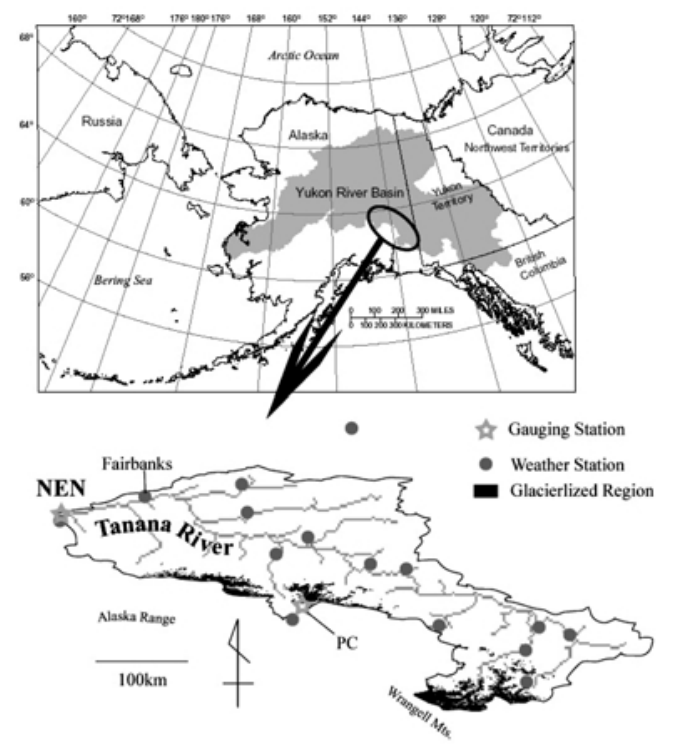

Fig. 1 Yukon River basin (upper) and Tanana River basin (lower) (modified after Brabets et al., 2000). Site NEN and site PC are USGS gauging stations of river stage. Fifteen weather stations are located in the Tanana River basin. Glacierized regions occupy $5.6 \%$ of the Tanana River basin area.

(M arch, 2000; Kido et al., 2007) ，兴のデータを 流域内の水河域の代表点として, 当研究では多く 用いる。

\section{II - 2 観測方法とデータセット}

流域内の NEN 地点及びPC 地点に米国地質調査 所 (USGS) の水位観測点があり, 光の日流量デー 夕の提供を受けた。また, NEN 地点に赤外線後方 散乱式濁度計 (アレック電子 KK 製, MTB-16K 型, 測定範囲 $0 \sim 2000 \mathrm{ppm}$, 測定精度 \pm 40ppm) を設置し，2000 年から 2005 年の $6 〜 9$ 月に濁度 の連続観測を行った。1 時間ごとに，1秒間隔で 10 サンプル記録されたデジタル信号 (瞬間 N 值) を平均し， N 值の 1 時間間隔の時系列を得た。 $N$ 值を事前の実験で得られた式を用いて濁度 (ppm) に変換した後, 濁度と現地て数回採取した河川水 の懸濁物質濃度 (suspended sediment concentration: 以下 SSC) (mg/l) の間で回帰式を作って濁度を 変換し, 全期間のSSC を得た。さらに,SSC に流 
量を乗じて浮流土砂流出量 $(\mathrm{kg} / \mathrm{s})$ を求めた。NEN 地点においては, 浮流土砂流出量が掃流土砂流出 量よりもオーダー的に大きく（知北ほか，2002）， 浮流土砂流出量のみで流出土砂に関する議論をし ても問題ないと判断した。

日平均気温と日降水量の気象データは, 米国海 洋大気庁 (NOAA) 及び米国西部気象センター (WRCC) の気象観測点 15 箇所のデータが提供 された。流域内の気象観測点から大きく離れた 地域では, より近い流域外の気象観測点のデー タを使用した。各気象観測点の值を適用する領 域は，ティーセン法で決定した。気温については DEM (digital elevation model) と気温減率 (-0.6 $\left.{ }^{\circ} \mathrm{C} / 100 \mathrm{~m}\right)$ を用いて高度補正を行った。降雨につ いても高度効果を考慮するため，1961 年〜 1990
年間の平均の 6 月雨量データマップ (The Climate Source, Inc.）を用いて補正を行った。关の結果， 補正された雨量は観測値の約 1.3 倍となった。

2005 年 6 〜 月にはNEN 地点において約 1 週間おきに採水し, 溶存 $\mathrm{SiO}_{2}$ 濃度を比色分析法 (QuAATro, Bran Luebbe, Inc.) で測定した。ま た，PC 地点においても 2005 年 9 月に 2 回採水し $\mathrm{SiO}_{2}$ 濃度を測定した。

III 観測結果

2002 年 6 〜 月及び 2005 年 6 〜 月における NEN 地点の流量・SSC と浮流土砂流出量, NEN 地点及び水河域の気温，及び流域全体の日雨量を Fig. 2 に示す。
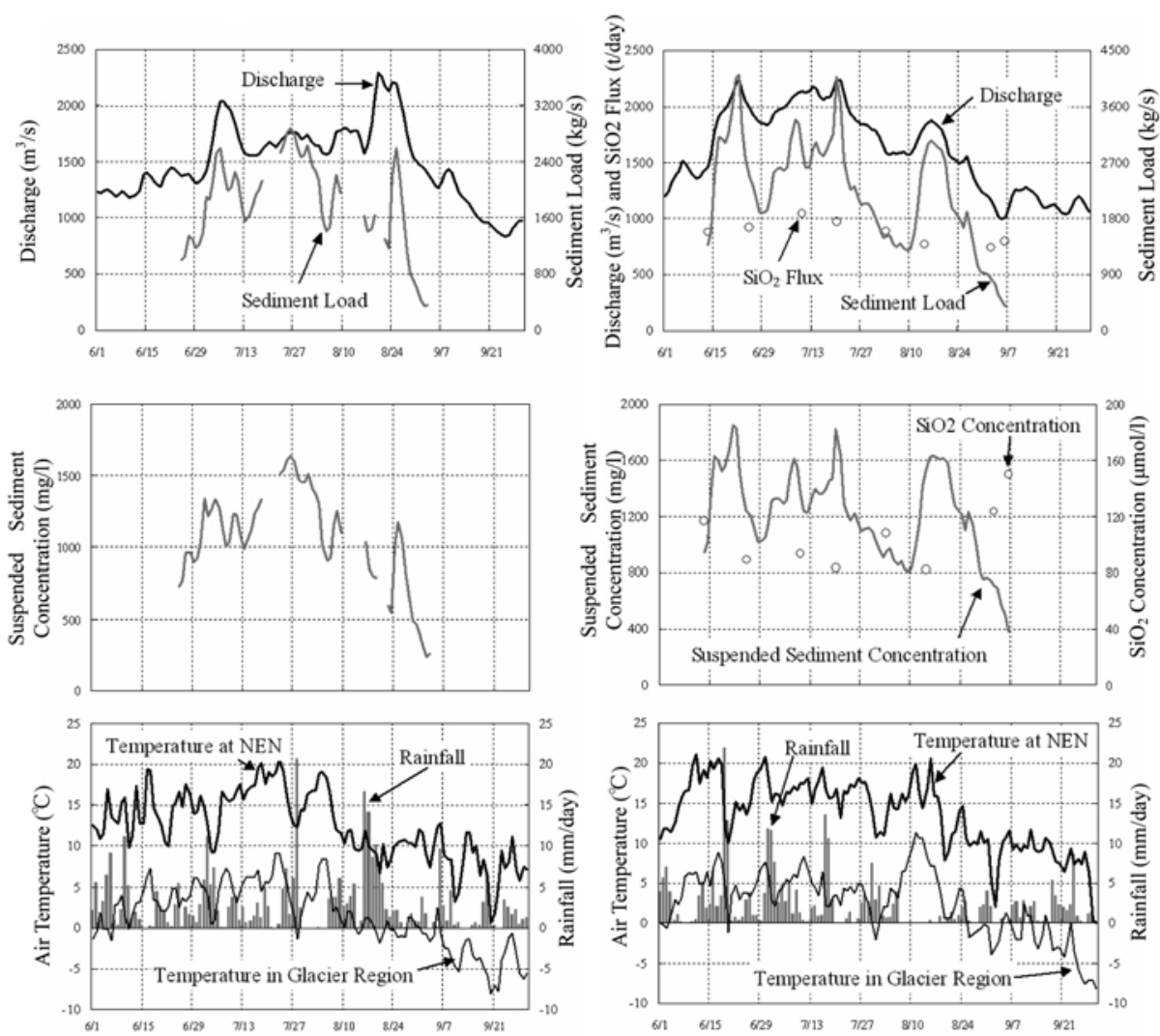

2002

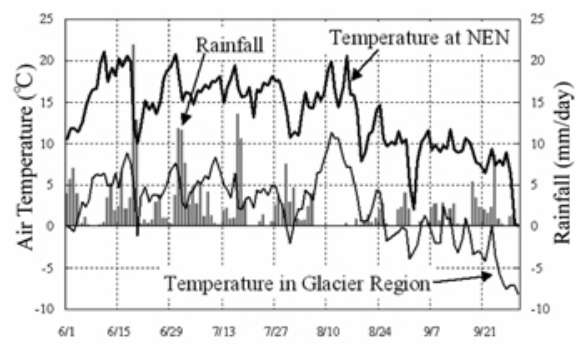

2005

Fig. 2 Temporal variations of discharge, sediment load, suspended sediment concentration (SSC) and air temperature at site NEN, air temperature in the glacier region and rainfall in the Tanana River basin in the summer of 2002 and 2005. $\mathrm{SiO}_{2} \mathrm{Flux}$ and $\mathrm{SiO}_{2}$ concentration in 2005 are also shown. 
2002 年の 7 月 1 日〜 5 日と 8 月 16 日〜 20 日， 2005 年の 6 月 19 日〜 20 日と 8 月 17 日〜 18 日に は比較的大きな降雨イベントが流域内で広く起 こっており, NEN 地点の流量は降雨に数日遅れ て大きく増加している。しかし，2002 年 7 月 28 日の降雨イベントでは主に上流域でのみ降雨が起 こっており，この年最大の日雨量を記録している にも関わらず流量の増加がほとんど見られない。 これは, 広大な流域を水が流下してくる過程で流 量のピークが大きく減衰するとともに，一部の水 が流域内に貯留されることを示唆している。

2005 年の 8 月 11 日〜 22 日には比較的大きな流 量ピークがあるが，これには相当する降雨イベン トが存在せず，代わりに水河域の気温が大きく上 昇している。このことから，この流量ピークは源 頭部の気温上昇に伴う水河融解が主な要因と考え られる。

SSC と浮流土砂流出量，流量を比べると，SSC と浮流土砂流出量は変動傾向が良く似ており，流 量よりもSSC の変化が土砂流出量に大きく影響 している。浮流土砂の起源としては主に永河流動 による水河底での浸食, 河道浸食及び凍土域での 浸食が考えられるが, 凍土域は浸食を受けにく く，水河をもたない流域内河川のSSC が水河域 のPC 地点に比べて 1 オーダー以上低い(知北ほ か , 2002) ことから，主な供給源は水河域であり， その土砂の一部が河道に堆積し流量増大時に再浸 食されていると思われる。実際に，2005年8月 11 日〜 22 日の水河起源と思われる増水イベント中 にはSSC も大きく増大している。2002 年の 7 月 13 日〜 8 月 15 日にも SSC の増大期間があるが， これは光れほど流量の増大を伴わない。しかし SSC のピークに 5 日程度先行して気温のピークが 来ており, 弚れに伴う融解流出が流送土砂の起源 と思われる。

$\mathrm{SiO}_{2}$ 濃度の変動傾向を見ると流量と逆相関して おり, $\mathrm{SiO}_{2}$ フラックスは変動が小さく安定してい る。 $\mathrm{SiO}_{2}$ は浸透の際に土鋊と接触している時間あ るいは距離が产の濃度形成に強く影響しており (恩田ほか, 1996)， $\mathrm{SiO}_{2}$ 濃度の高い深い帯水層
からの地下水流出が安定した供給源となっている と思われる。

\section{IV 水収支}

観測データから流域での水の収支量を計算し， その特徵を明らかにするとともに, 計算の結果を タンクモデルによる流出解析に用いる。

まず, 流域を弚の被覆特性から水河域と光れ 以外の凍土域の二つに分けた。凍土域には, 不 連続永久凍土帯や湿地帯などが含まれる。水河 域への涵養は降水 $P(\mathrm{~mm} /$ day $)$ 及び水河融解 $M$ $(\mathrm{mm} /$ day $)$, 凍土域への涵養は降水 $P$ と凍土融 解 F ( $\mathrm{mm} /$ day) であり, 流域からの損失は凍土 域の蒸発散 ET (mm/ day) と NEN 地点での河川 流出 $D_{s}(\mathrm{~mm} /$ day $)$ とした。水河域での昇華や蒸 発, 流域外への地下水流出は無視できるものとし た。期間は，2000 年から 2005 年の 6 月〜 9 月で ある。水収支式は次式で表される。

$$
\Delta \mathrm{S}_{\mathrm{s}}+\Delta \mathrm{S}_{\mathrm{a}}=\mathrm{P}+\mathrm{M}+\mathrm{F}-\mathrm{D}_{\mathrm{s}}-\mathrm{ET}+\mathrm{e}
$$

ここで, $\Delta S_{s}$ : 流域内水貯留の季節変化量 $(\mathrm{mm} /$ day $), \Delta \mathrm{S}_{\mathrm{a}}$ : 季節変化 $\left(\Delta \mathrm{S}_{\mathrm{s}}\right)$ 以外の流域 内水貯留の変化量 $(\mathrm{mm} / \mathrm{day})$ 及び e: 推定誤差で ある。 $\Delta \mathrm{S}_{\mathrm{s}}$ 值は年によって変動せず, 1 年間の積 算値は 0 になる量である。涵養が多い夏季は正の 值をとり (貯留量増加), 涵養がほとんど無く蒸 発散も少ない冬季はほぼ $\Delta S_{a}=-D_{s}$ の関係を満た し，負の值をとっている (貯留量減少) と考えら れる。一方, $\Delta \mathrm{S}_{\mathrm{a}}$ 值は兴の年の涵養量によって変 動し， 1 年間の積算值も年によって異なる。

水河域と凍土域の二つに分けた流域をティーセ ン法で分割し, 各気象観測点の観測值を適用する 範囲を決めた。乥して, 弚れ光れの気象観測点ご とに下記の方法で函養量及び損失量を求めた。

蒸発散量を求めるため, 緯度と視赤緯から計算 した可能日照時間と日平均気温から Hamon 法 (Hamon, 1963; Dingman, 2002) を用いて日可能 蒸発散量 PET を計算した。次に, Pike 方程式を 用いて (Dingman, 2002) 6 月〜 9 月の総降水量 $P$ 
と総可能蒸発散量 PETs から総実蒸発散量 $E T_{s}$ を 求めた。最後に蒸発散比 $\mathrm{y}=E T_{s} / P E T_{s}$ を計算し, 各年のY 值は一定として,PET に乗じて日実蒸発 散量 ET を求めた。

水河融解は, 高度補正した日平均気温を元に下 記の degree day 法で計算した (Braithwaite, 1995; Kido et al., 2007)。

$$
M=T_{a} \times f
$$

ここで , f : degree day ファクター $\left(\mathrm{mm} /\right.$ day $\left.\cdot{ }^{\circ} \mathrm{C}\right)$ である。f 値は地域や表面の状態によって変わる ので, PC 地点上流にあるガルカナ水河で得られ た値 (M arch (2000) によって雪面上で $3.5 〜 5.0$ ， 水面上で $7.0 \sim 10.0)$ を参考に, 雪面上で 3.5 , 水 面上で 7.0 とした。水河上の雪線高度は季節が進 むにつれて上昇し, 裸永域が徐々に増えるため, 同水河で観測された 2001 年雪線高度変化 (Kido et al., 2007) より雪線高度を段階的に引き上げて 融解量を計算した。

凍土域からの融解量 $\mathrm{F}$ は, 流域内の凍土分布が 不明なことから，兴の量を推定することは困難で ある。光こで, 水収支式の残差から凍土融解量と 貯留変化量の差を計算し, 凍土融解の影響につい て検討した。残差 $R_{d}$ は , (1) 式左辺から F を引い た $R_{d}=\Delta S_{s}+\Delta S_{a}-F-e て ゙$ 表わされる量で，(1) 式右辺から $F$ を減じた $R_{d}=P+M-D_{s}-E T$ を計算 することで得られる。

以上より計算された, 各気象観測点の日雨量・ 水河融解量・蒸発散量の値を流域全体で面積加重 平均して，全体の水収支を計算した。Table 1 に
各年 $6 \sim 9$ 月の平均日雨量 · 水河融解量 · 蒸発散 量・流出高及び水収支の残差を示す。6 年間の 平均日水河融解量は $0.78 \mathrm{~mm} /$ day で平均日雨量 $2.24 \mathrm{~mm} /$ day の約 1/ 3 となった。平均日蒸発散量 は $1.42 \mathrm{~mm} /$ day となり, 凍土域では雨量の 6 割程 度か蒸発散で失われている。

涵養量の年毎のばらつきは損失量のばらつきと 比べて大きく, 水河融解量は最小の 2000 年と最 大の 2004 年の間で約 1.8 倍, 雨量は最小の 2004 年と最大の 2002 年の間で約 1.9 倍の開きがある。 しかし, 流出量は比較的安定しており，これは流 域内貯留がバッファーとして働いているからと考 えられる。涵養量と損失量の残差は, 流域内貯留 の変化量 $\Delta \mathrm{S}_{\mathrm{s}}+\Delta \mathrm{S}_{\mathrm{a}}$ から凍土融解量 $\mathrm{F}$ を減じたも のであり, 総涵養量が少ない年に残差（負值の絶 対值) が大きくなる傾向がある。これは, 涵養量 が少ない年には流域内貯留が排出されて $\Delta \mathrm{S}_{\mathrm{a}}$ 値が 負値になるためと考えられる。逆に, 涵養量が多 い年には流域内貯留が増加して $\Delta \mathrm{S}_{\mathrm{a}}$ 值が正值にな り, 流量を安定させていると思われる。2002 年 及び 2005 年の雨量 ·融解量 ·蒸発散量 · 流出高及 び6月1日を基準にした水収支の残差の積算を Fig. 3 に示す。これによると, 降雨による涵養の 少ない 2005 年 8 月後半から 9 月前半にかけて貯留 分が排出されていることがわかる。2002 年は降 雨が多かったために $\Delta S_{a}$ 值が大きな正の值とな り，F と相殺して残差 $R d$ がほぼ 0 なったと思われ る。

2000 年〜 2005 年の残差を平均すると, 年変動 する $\Delta \mathrm{S}_{\mathrm{a}}$ の影響を除外した值 $\overline{\mathrm{R}_{d}}=\Delta \mathrm{S}_{\mathrm{s}}-\overline{\mathrm{F}}-\mathrm{e}$ が

Table 1 Glacier-melt amount, rainfall, evapotranspiration, runoff height and residual ( $\mathrm{mm} /$ day) averaged for June to September of 2000 to 2005.

\begin{tabular}{ccccccccc}
\hline Year & 2000 & 2001 & 2002 & 2003 & 2004 & 2005 & Average & S.D. \\
\hline Glacier-melt & 0.62 & 0.72 & 0.65 & 0.76 & 1.1 & 0.81 & 0.78 & 0.17 \\
Rainfall & 2.79 & 1.90 & 2.81 & 2.12 & 1.48 & 2.35 & 2.24 & 0.52 \\
\hline Total Input & 3.41 & 2.62 & 3.46 & 2.88 & 2.58 & 3.16 & 3.02 & 0.38 \\
Evapotranspiration & 1.59 & 1.31 & 1.54 & 1.35 & 1.24 & 1.48 & 1.42 & 0.14 \\
Runoff Height & 2.04 & 2.00 & 1.98 & 1.81 & 1.90 & 2.15 & 1.98 & 0.12 \\
\hline Total Output & 3.63 & 3.31 & 3.52 & 3.16 & 3.14 & 3.63 & 3.40 & 0.23 \\
Residual & -0.22 & -0.69 & -0.06 & -0.28 & -0.56 & -0.47 & -0.38 & 0.23 \\
\hline
\end{tabular}



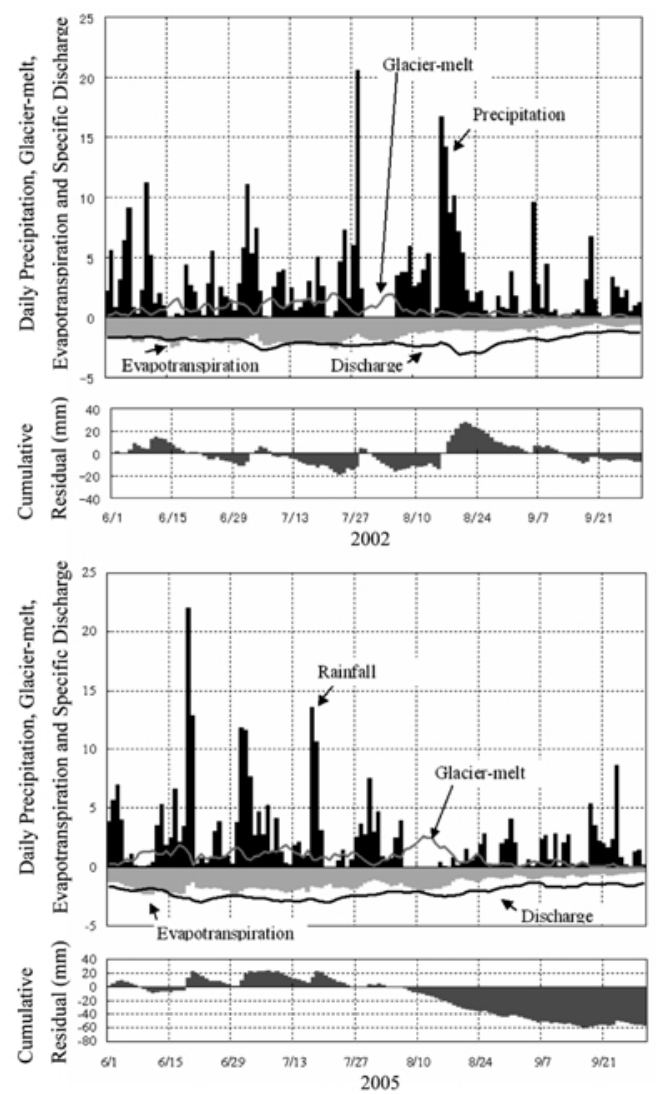

Fig. 3 Temporal variations of discharge, evapotranspiration, rainfall, glacier-melt and residual (water storage minus ice-melt in permafrost) in the summer of 2002 and 2005.

得られ， $R_{d}$ 値の正負を逆にすると凍土域からの 融解から夏季の貯留増加量を引いた值となる。こ こで， $\Delta \mathrm{S}_{\mathrm{s}}$ の涵養源が涷土融解であると仮定する と, - $\overline{R_{d}}$ 值は凍土融解量から流域内に残留する量 を減じた值，つまり凍土融解水のうち流出または 蒸発散によって流域外に出る量となる。融解面は 地中数十 $\mathrm{cm}$ 〜数 $\mathrm{m}$ の深さにあるため, 蒸発散に よって失われる量は少ないと考えると，- $\overline{\mathrm{R}_{\mathrm{d}}}$ 值は 凍土融解流出量となる。光の結果, 計算された凍 土融解流出量は $0.38 \mathrm{~mm} /$ day と小さな値となっ た。ただし， $\Delta \mathrm{S}_{\mathrm{s}}$ の涵養源が凍土融解のみではな いことや，水河融解量等の見積もりの誤差がある ことから，この值の信頼性は必ずしも高くない。
計算された凍土融解流出量を Kuchment et al. (2000) がロシア・コリマ川流域で得た 5 月〜 8 月の凍土域からの日平均融解流出量 $0.88 \mathrm{~mm} / \mathrm{day}$ と比べると值が小さいが, タナナ川流域の凍土は 不連続である点を考慮すると, 計算された凍土融 解流出量はオーダー的に妥当な值と思われる。

\section{$\vee$ 流出解析}

\section{V- 1 水の流出解析}

以後は流量観測点 (NEN 地点) で得られた 水・土砂・化学物質の流出時系列を流出特性の 異なる水河域と凍土域を区別したタンクモデル (Sugawara, 1972) で再現することによって, 水 河域及び東土域の流出への寄与を定量的に評価す る。本研究の対象流域においては, 2002 年及び 2003 年の河川水の流出に関する流出解析が知北 ほか (2006) によって行われているが, 凍土域か らの流出をひとつのタンクで再現した結果, 水が 流域を流下してくる際にピークが減衰することを 考慮できなかった。关こで, 流域を三つにわけ， さらに兴の流出機構の違いから, 水河域と光れ以 外の凍土域に分けてタンクを設けた (Fig. 4)。水 河域のタンクはKido et al. (2007) を参考に一段， 凍土域は表面流出・中間流出・基底流出に対応す る三段タンクとした。水河域タンクへの入力は水 河融解と降雨, 凍土域タンクへは降雨を与え, 凍 土域の表面流出タンクと中間流出タンクからは蒸 発散を引いた。凍土域からの融解については, 融 解量が不確定ではあるものの, 值が比較的小さく 融解量の日変動も小さい (Kuchment et al., 2000) ことから, これをタンクの初期貯留量と蒸発散が ない基底流出タンクからの流出量の一部とみなし て再現した。1 時間ステップでこれらの入力を与 え, 残ったタンク内の水量に比例した量を計算流 出量として出力し, 実測流量と比較した。再現期 間は 2000 年〜 2005 年の 6 月〜 9 月で, 各年の 5 月を助走計算期間とした。

各タンクのパラメータは ,2002 年の実測流量を 最もよく再現するように最適化し，他の年で光の 


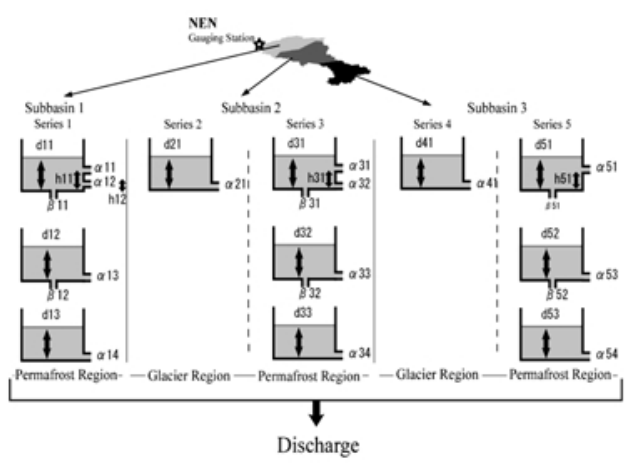

Fig. 4 Tank structure in the tank model applied to the Tanana River basin.

妥当性を検証した。Table 2 に示したパラメータ は光れ艺れ，一時間あたりの流出率 $a\left(\mathrm{~h}^{-1}\right)$ ，一時 間あたりの浸透率 $\beta\left(\mathrm{h}^{-1}\right)$ ，孔の高さ $\mathrm{h}(\mathrm{mm})$ ，初 期貯留高 $d(\mathrm{~mm})$, 遅れ時間 $D(h)$ である。各 パラメータは流域の地下構造などの流出特性を表 すものであり, 表面からの早い流出に対応する $a_{i 1}$ と $\alpha_{i 2}$ (i はタンクの列番号) の值は, 流域下 流部で大きく上流部では小さくなるように設定し た。凍土域の浸透率及び基底流出タンクの流出率 は, 地域による変化が小さいと思われるので, な るべく近い値をとるよう設定した。遅れ時間は， 上流に行くごとに 1 日ずつ増やした。水河融解流 出量は, 気温に対して遅れて反応する (Kido et al., 2007) ことから水河域タンクは凍土域タンク よりさらに2 日遅らせた。
2002 年の実測流量にベストフィットさせたパ ラメータを用いて 2000 年〜 2005 年の流量を再現 した結果を, Fig. 5 に示す。平均自乗誤差の平方 根 (RM SE) は平均流量の $20 \%$ 以下 $(6.6 \%$ (2002 年) 19.7\% (2001 年)), 相関係数 R は 0.68 (2000 年)〜 0.97 (2002 年)とよい再現性を示した (Table 3)。同一のパラメータで複数年の流出を再現でき たことは, パラメータが流域の流出特性をよく表 せていると同時に, タナナ川の流出構造が年毎に 大きく変わらず安定しており, 気温と雨量データ のみから流量がある程度推定できることを示して いる。ただし，2000 年 8 月 16 日より前の期間や 2001 年 8 月 1 日前後, 及び 2003 年の 8 月 12 日〜 8 月 23 日ではピーク流量を過小評価している。こ の理由として，いずれの期間も氷河からの流出量 が $1000 \mathrm{~m}^{3} / \mathrm{s}$ を超える高温の日があり, 水河内の 水路が発達して内部貯留が吐き出された (Kido et al., 2007) 結果, 実測流量の方が大きくなったこ とが考えられる。また, アルベド等の年による違 いにより, degree day ファクターか変化した可能 性もある。2005 年の降雨時の再現性の悪さは, 降 雨が局地的に起きたため, 実際の流域内降雨分布 を 15 箇所の気象観測点では捉えきれなかったこ とが原因と思われる。今後, 熱収支を用いたより 正確な融解量推定, 雨量レーダーを用いた降雨分 布の推定をする必要がある。

計算流出量に占める水河融解流出量は平均約

Table 2 Tank parameters for the Tanana River basin.

\begin{tabular}{lllll}
\hline \multicolumn{1}{c}{$D_{1}=24[\mathrm{~h}]$} & \multicolumn{1}{c}{$\mathrm{D}_{2}=96$} & \multicolumn{1}{c}{$\mathrm{D}_{3}=48$} & \multicolumn{1}{c}{$\mathrm{D}_{4}=120$} & \multicolumn{1}{c}{$\mathrm{D}_{5}=72$} \\
\hline $\mathrm{a}_{11}=1.4 \times 10^{-3}\left[\mathrm{~h}^{-1}\right]$ & $\mathrm{a}_{21}=1.9 \times 10^{-2}$ & $\mathrm{a}_{31}=2.4 \times 10^{-5}$ & $\mathrm{a}_{41}=6.7 \times 10^{-3}$ & $\mathrm{a}_{51}=1.2 \times 10^{-4}$ \\
$\mathrm{a}_{12}=1.6 \times 10^{-3}$ & & $\mathrm{a}_{32}=4.7 \times 10^{-4}$ & & $\mathrm{a}_{52}=0$ \\
$\mathrm{a}_{13}=3.1 \times 10^{-4}$ & & $\mathrm{a}_{33}=2.7 \times 10^{-3}$ & & $\mathrm{a}_{53}=1.0 \times 10^{-2}$ \\
$\mathrm{a}_{14}=3.4 \times 10^{-4}$ & & $\mathrm{a}_{34}=3.4 \times 10^{-4}$ & & $\mathrm{a}_{54}=3.4 \times 10^{-4}$ \\
\hline$\beta_{11}=1.6 \times 10^{-3}\left[\mathrm{~h}^{-1}\right]$ & & $\beta_{31}=1.1 \times 10^{-3}$ & & $\beta_{51}=2.1 \times 10^{-3}$ \\
$\beta_{12}=6.2 \times 10^{-2}$ & & $\beta_{32}=6.2 \times 10^{-2}$ & $\beta_{52}=6.2 \times 10^{-2}$ \\
\hline$h_{11}=10.6[\mathrm{~mm}]$ & & $\mathrm{h}_{31}=4.0$ & & $\mathrm{~h}_{51}=1.9$ \\
$\mathrm{~h}_{12}=3.1$ & & $\mathrm{~h}_{32}=0$ & & $\mathrm{~h}_{52}=0$ \\
\hline $\mathrm{d}_{11}=0.6[\mathrm{~mm}]$ & $\mathrm{d}_{21}=90.0$ & $\mathrm{~d}_{31}=0.6$ & $\mathrm{~d}_{41}=150.0$ & $\mathrm{~d}_{51}=0.6$ \\
$\mathrm{~d}_{12}=10.0$ & & $\mathrm{~d}_{32}=10.0$ & & $\mathrm{~d}_{52}=10.0$ \\
$\mathrm{~d}_{13}=100.4$ & & $\mathrm{~d}_{33}=100.4$ & & $\mathrm{~d}_{53}=100.4$ \\
\hline
\end{tabular}



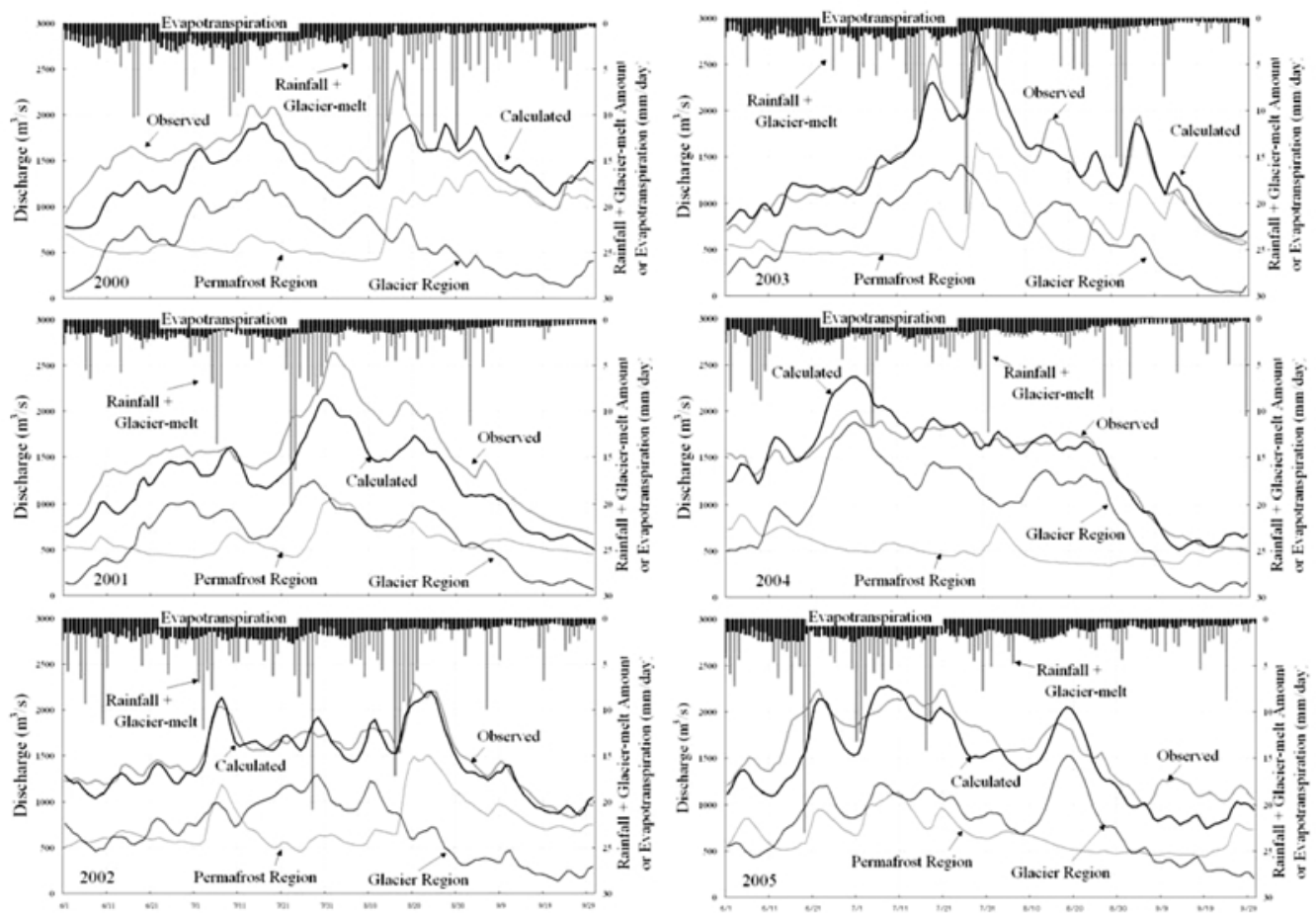

Fig. 5 Comparison between observed and calculated hydrographs in 2000 to 2005. The calculated discharge is divided into the discharge from permafrost regions and that from glacier regions. The rainfall plus glacier-melt and evapotranspiration are also shown.

Table 3 Reproducibility of calculated discharge, observed mean discharge and contribution of glacial-melt to the calculated discharge.

\begin{tabular}{crrrrrr}
\hline Year & 2000 & 2001 & 2002 & 2003 & 2004 & 2005 \\
\hline Correlation coefficient R & 0.68 & 0.96 & 0.97 & 0.96 & 0.96 & 0.92 \\
RM SE $\left(\mathrm{m}^{3} / \mathrm{s}\right)$ & 270 & 296 & 99 & 157 & 156 & 241 \\
Observed mean discharge $\left(\mathrm{m}^{3} / \mathrm{s}\right)$ & 1540 & 1503 & 1490 & 1365 & 1431 & 1621 \\
\hline $\begin{array}{c}\text { Contribution of glacial-melt } \\
\text { (water volume in \%) }\end{array}$ & 33 & 44 & 36 & 41 & 58 & 43 \\
\hline
\end{tabular}

43\%であり (Table 3)，流域の水河被覆面積率約 $5.6 \%$ と比べて非常に大きい。このことから，温 暖化等の影響による一時的な流量の増加，及び光 の後の水河縮退による流量の大幅な減少をもたら す可能性がある。

\section{V- 2 土砂流出解析}

一般的に，土砂の供給源が明らかな場合，土砂 流出量は流量の累乗に比例するという関係にある
(大澤・酒井, 2002)。光こで, 2002 年の NEN 地点における水河域からの計算流出量 $\mathrm{Q}_{g}\left(\mathrm{~m}^{3} / \mathrm{s}\right)$ と浮流土砂流出量 $\mathrm{L}(\mathrm{kg} / \mathrm{s})$ の関係を調べると， $L=0.049 Q_{g}^{1.6}\left(R^{2}=0.77\right)$ という関係にあることがわ かった (Fig.6)。これは, 土砂流出は氷河域が主 な起源で, 弚れを凍土域からの流出が希釈して NEN 地点のSSC を決めていることを示唆してい る。このことから, 水河域からの流量と浮流土砂 流出量の間に L-Q 式を適用し SSC を再現した。L- 
$Q$ 式は次式で表される。

$L=A \cdot Q^{b}$

ここで, 土砂流出量 $\mathrm{L}(\mathrm{kg} / \mathrm{s})$, 流出量 $\mathrm{Q}\left(\mathrm{m}^{3} / \mathrm{s}\right)$,

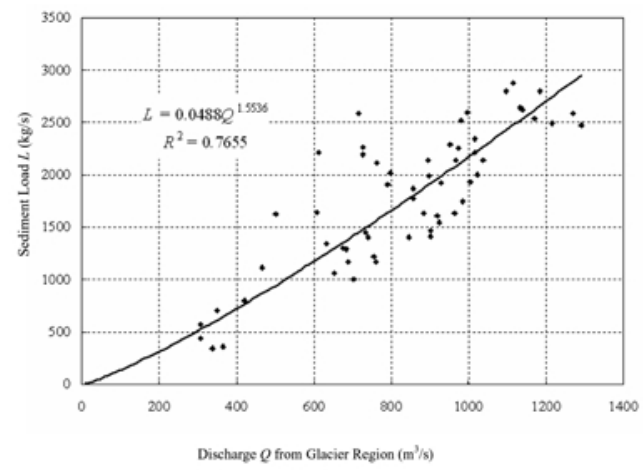

Fig. 6 Correlation between observed sediment load at site NEN and calculated discharge from glacier region in 2002.
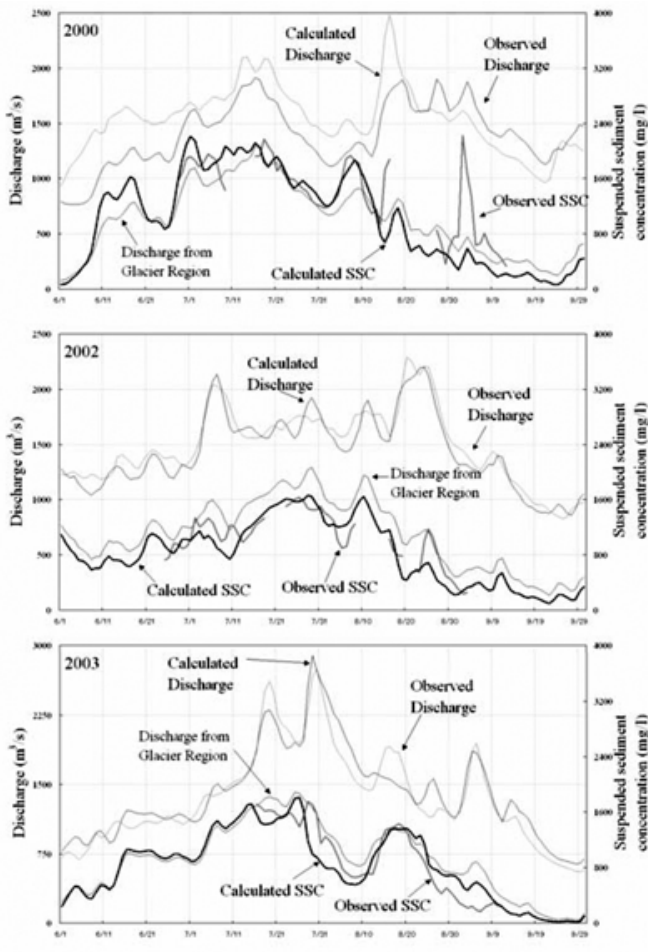

定数 A,b である。浸食される土砂の特性を表す $b$ 值は変動しないと仮定し，2002 年の水河域から の流量と土砂流出量の関係から b の值を 1.6 と決 め, この值を全ての年に適用した。浸食される土 砂の存在量を表す $\mathrm{A}$ 值は, 年毎に変化すると仮定 し，二つの水河域タンクごとに毎年最適值を与え た。

SSC の再現結果を Fig. 7 に示す。2001 年は濁度計 センサーが流下物に覆われたため欠測となった。 実測 SSC と観測 SSC の相関係数 R は 0.70 (2005 年) 0.87 (2002 年) となり, 全体の変化傾向を再 現することが出来た。RM SE は平均SSC の $29.2 \%$ (2000 年), $10.1 \%$ (2002 年), $26.4 \%$ (2003 年), $14.1 \%$ (2004 年), $19.0 \%$ (2005 年) となった。 2000 年の RM SE が大きいのは 9 月 2 日のわずかな 流量増大に対して実測 SSC が大きく反応してい るためであり，このような $100 \mathrm{~m}^{3} / \mathrm{s}$ 程度の流量増
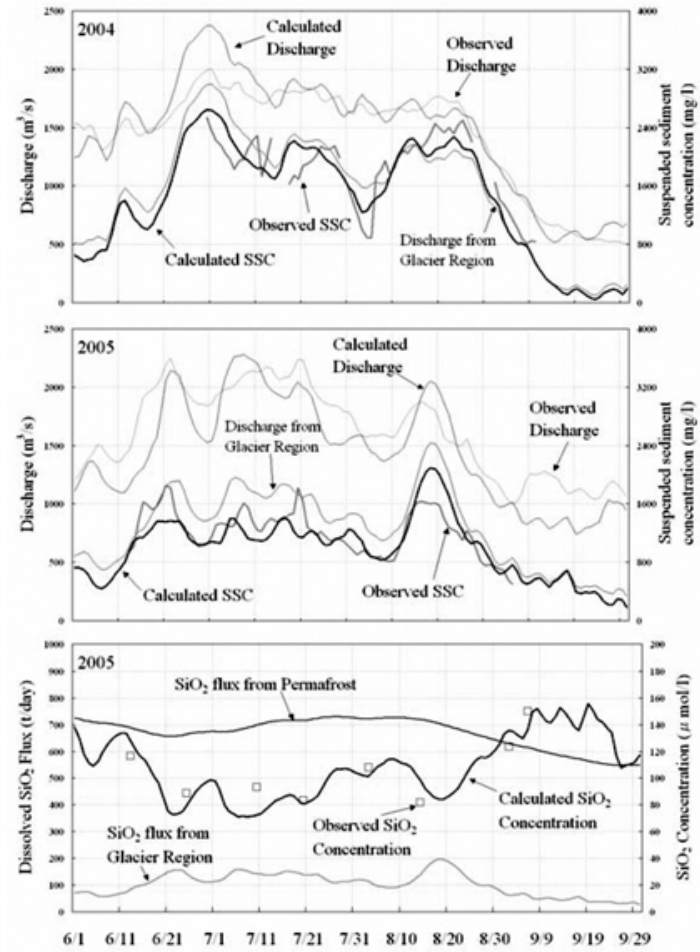

Fig. 7 Comparison between observed and calculated SSC series in 2000, 2002 and 2003 (left side), 2004 (upper right) and 2005 (center right). The observed discharge and the calculated discharge from the glacier regions are also shown. Lower right figure shows observed and calculated $\mathrm{SiO}_{2}$ series in 2005. The calculated $\mathrm{SiO}_{2}$ flux from the glacier and the permafrost regions are also shown. 
大で $2000 \mathrm{mg} / \mathrm{I}$ 近い SSC の上昇は他の年では認め られなかった。

9 月には, 夏季に流れてきた土砂が大量に河道 に貯まっており，弚の巻上げを濁度計が計測した ことが過剩な值の原因と思われる。

二つある水河域タンクの A 值を年毎に平均する と, 0.046 (2000 年), 0.032 (2002 年), 0.031 (2003 年), 0.036 (2004 年)，0.033 (2005 年) と近い值 に収束した。このことから，タナナ川流域の土砂 供給は年によらず安定していることが示唆され る。また, 土砂流出の起源として水河域のみ考慮 すればNEN 地点のSSC を説明できることから， 流送土砂はほとんどが涾河域から供給されている と思われる。つまり, 土砂流出量は水河域の気温 に大きく依存しており，流量同樣温暖化の影響が 懸念される。

\section{V- $3 \mathrm{SiO}_{2}$ 流出解析}

$\mathrm{SiO}_{2}$ は凍土域からの基底流出が主な供給源で, 兴の他に水河域からも多少の流出があると考えら れる。乥こで, タンクモデルで分離した基底流出 と水河域からの流出に一定濃度の $\mathrm{SiO}_{2}$ を元, $\mathrm{SiO}_{2}$ 流出を再現することを試みた。水河域からの 流出は, 2005 年 9 月 7 日の PC 地点での観測結果 $(26.8 \mu \mathrm{mol} / \mathrm{l}, 29.2 \mu \mathrm{mol} / \mathrm{l})$ や Anderson et al. (2000)のアラスカ・Bench 水河での值を参考に， $25 \mu \mathrm{mol} / \mathrm{l}$ で一定とした。基底流出からの供給 は,NEN 地点での観測結果をもっとも良く再現で きる一定値 $268 \mu \mathrm{mol} / \mathrm{l}$ を与えた。

再現結果を Fig. 7 右下に示す。実測と計算 $\mathrm{SiO}_{2}$ 濃度の相関係数 $\mathrm{R}$ は $0.86, \mathrm{RM} \mathrm{SE}$ は平均 $\mathrm{SiO}_{2}$ 濃度 の約 $12 \%$ で良い再現性を示し， $\mathrm{SiO}_{2}$ の起源は主 に凍土域からの基底流出と永河域からの流出であ ると判断される。 $\mathrm{SiO}_{2}$ フラックスへの寄与率は, 凍土域 $87 \%$ ，水河域 13\%であった。水河域から の流出は濃度が低く，凍土域からの流出を希釈す る働きをしている。 $\mathrm{SiO}_{2}$ フラックスに与える影響 は小さいことから, 気温変動により水河融解量が 変動しても $\mathrm{SiO}_{2}$ の総流出量はあまり変動しない と思われる。
$V I \quad$ 結論と今後の課題

本論文では, 流域内に水河域と凍土域を持つア ラスカ・タナナ川において，流域水収支評価とこ れに基づくタンクモデルを用いた流出解析を行 い, 水河域及び東土域からの流出が夏季の水・土 砂・化学物質の流出に及ぼす寄与を定量的に評価 した。弚の結果，全流域面積の約 $5.6 \%$ に過ぎな い水河域からの融解流出量は全流量の約 $43 \%$ を 占めることがわかった。流送土砂の供給源はほと んどが水河域であり, 溶存態 $\mathrm{SiO}_{2}$ は約 $87 \%$ が凍 土域から, 約 $13 \%$ が水河域から供給されているこ とがわかった。今後は, 海洋生態系に大きな影響 を与える $\mathrm{PO}_{4} や \mathrm{NO}_{3}$ の流出機構の解明及び解析対 象流域のユーコン川全体への拡大を行うことが必 要である。

\section{謝辞}

現地観測にあたり，米国地質調査所 (USGS) フェアバンクス支所・水資源部の M att Schellekens 氏 ,Dennis Trabant氏,Rod S. M arch氏,及びYutana Barge Line 社・社長 M att Sweetsir 氏に大変お世 話になった。また, USGSからは流量データの提 供を受けた。ここに厚くお礼申し上げます。アラ スカ大学国際北極圏研究センター (IARC) 所長. 赤祖父俊一博士, IARC 助教授・ Yongwon Kim 博 士及び事務員・Yoriko Freed 氏には現地受け入れ 機関として多くの便宜を図っていただいた。深く 感謝いたします。

参考文献

大澤和敏, 酒井一人 (2002): 降雨-土砂流出解析 のための浮流土砂流出モデルの構築 - 沖縄県に おける赤土流出モデル化に関する研究 - . 農業 土木学会論文集, N o.217，65-70.

恩田祐一, 奥西一夫, 飯田智之, 辻村真貴 (1996): 水文地形学, 古今書院, 267p. 
知北和久, 熊井隆二, 平山賢太 (2002)：アラス カ・ユーコン河の土砂流出機構に関する研究. 「永久凍土帯の水循環特性解明の研究」2001 年 度報告書，131-157。

知北和久, 森田俊一, 和田知之, 城戶大作 (2006): 亚寒帯河川流域における水・土砂流出機構 - ア ラスカ・タナナ川 - . 日本水文科学会誌, 36, 59-69.

Anderson, S. P., Drever, J. I., Frost, C. D. and Holden, P. (2000): Chemical weathering in the foreland of a retreating glacier. Geochimica et Cosmochimica Acta., 64, 1173-1189.

Brabets, T. P., Wang, B. and M eade, R. (2000): Environmental and hydrologic overview of the Yukon River Basin, Alaska and Canada. WaterResources Investigations Report 99-4204, U.S. Geological Survey, 106p.

Braithwaite, R. J. (1995): Aerodynamic stability and turbulent heat flux over a melting ice surface, the Greenland ice sheet. Jour. Glaciol., 41, 562-571.

Brown, J., Ferrians, Jr., O.J., Heginbottom, J.A., and M elnikov, E.S. (1997): CircumArctic map of permafrost and ground ice conditions. U.S. Geological Survey Circum-Pacific Map Series, M ap CP-45.

Chikita, K. A., Wada, T., Kudo, I., Kido, D., Narita, Y. and Kim, Y. (2007): Modeling discharge, water chemistry and sediment load from a subarctic river basin: the Tanana River, Alaska. IAHS Publications, 314, 45-56.

Dingman, S. L. (2002): Phisical Hydrology. $2^{\text {nd }}$ edition, Prentice-H all, N ew Jersey, 646p.

Ferrians, O.J., Jr. (1965): Permafrost map of Alaska. U.S. Geological Survey Miscellaneous Geologic Investigations M ap I-445, scale 1:2,500,000.

Guo, L., and M acdonald, R. W. (2006): Source and transport of terrigenous organic matter in the upper Yukon River: Evidence from isotope $(\delta 13 \mathrm{C}$, $\triangle 14 \mathrm{C}$, and $\delta 15 \mathrm{~N})$. Global Biogeochemical cycles, 20, GB2011, doi:10.1029/2005GB 002593

Hamon, R. W. (1963): Computation of direct runoff amounts from storm rainfall. IAHS Publ. 63, IAHS Press, Wallingford, UK.

Kido, D. Chikita, K. A. and Hirayama, K. (2007): Subglacial drainage system changes of the Gulkana Glacier, Alaska: discharge and sediment load observations and modeling. Hydrol Process., 21, 399-410.

Kuchment, L. S., Gelfan, A. N., Demidov, V. N. (2000): A distributed model of runoff generation in the permafrost regions. Jour. Hydrol., 240, 122.

M arch, R. S. (2000): M ass balance, meteorological, ice motion, surface altitude, runoff and ice thickness data at Gulkana Glacier, Alaska, 1995 balance year. Water-Resources Investigations Report, No. 00-0474, U. S. Geol. Surv., 117p.

Meade, R. H., Bobrovitskaya, N. N. and Babkin, V. I. (2000): Suspended-sediment and fresh-water discharges in the Ob and Yenisey rivers, 196088. Intern. Jour.E arth Sciences, 89, 461-469.

Sugawara, M . (1972): A M ethod for Runoff Analysis. Kyoritsu Shuppan Press, Tokyo (in J apanese) Woo, M.-K. and Marsh, P., (2005): Snow, frozen soils and permafrost hydrology in Canada, 19992002. Hydrol. Process, 19, 215-229.

(受付：2007年 2 月28日) (受理 : 2007年 7 月27日)

この論文に対する「討論」を2008年 2 月29日ま で受け付けます。 